\title{
Comparison of diet and prey selectivity of the Pyrenean desman and the Eurasian water shrew using next-generation sequencing methods
}

\author{
Marjorie Biffi ${ }^{a}, *$, Pascal Laffaille ${ }^{a}$, Jérémy Jabiol ${ }^{a}$, Adrien Andréb ${ }^{b}$ François Gillet ${ }^{b}$, \\ Sylvain Lamothe ${ }^{\mathrm{a}}$, Johan R. Michaux ${ }^{\mathrm{b}, \mathrm{c}}$, Laëtitia Buisson ${ }^{\mathrm{a}}$ \\ a EcoLab, Université de Toulouse, CNRS, INPT, UPS, 118 route de Narbonne, 31062 Toulouse cedex 9, France \\ b Laboratoire de Biologie Evolutive, Unité de Génétique de la Conservation, Université de Liège, Institut de Botanique B22, Quartier Vallée 1, Chemin de la \\ Vallée 4, 4000 Liège, Belgium \\ ' CIRAD, Agirs Unit, TA C- 22/E- Campus international de Baillarguet, 34398 Montpellier Cedex 5, France
}

\section{A R T I C L E I N F O}

\section{Article history:}

Received 9 December 2016

Accepted 12 September 2017

Handled by Laura Iacolina

Available online 14 September 2017

\section{Keywords:}

COI

Dietary overlap

Foraging strategy

Scat analyses

Semi-aquatic mammal

\begin{abstract}
A B S T R A C T
In this study, the interactions between two semi-aquatic mammals, the endangered Pyrenean desman Galemys pyrenaicus and the Eurasian water shrew Neomys fodiens, were investigated through the analysis of their summer diet using next-generation sequencing methods, combined with analyses of prey selectivity and trophic overlap. The diet of these predators was highly diverse including 194 and 205 genera for $G$. pyrenaicus and $N$. fodiens respectively. Overall, both species exhibited rather non-selective foraging strategies as the most frequently consumed invertebrates were also the most frequent and abundant in the streams. This supported a generalist foraging behaviour for G. pyrenaicus and N. fodiens in the study area. The Pianka index (0.4) indicated a significant but moderate dietary overlap as G. pyrenaicus mostly relied on prey with aquatic stages whereas prey of $N$. fodiens were mainly terrestrial. Moreover, no difference in G. pyrenaicus prey consumption was found in presence or absence of $N$. fodiens. A differential use of trophic resources through mechanisms such as plastic feeding behaviour or differences in foraging micro-habitat are likely to facilitate the coexistence between these two mammal species.
\end{abstract}

(c) 2017 Deutsche Gesellschaft für Säugetierkunde. Published by Elsevier GmbH. All rights reserved.

\section{Introduction}

Biodiversity conservation requires a thorough knowledge of the complex nature of interactions between species and their environment. According to the ecological niche theory (Hutchinson, 1957), sympatric species are expected to exhibit some niche differentiation in prey or habitat use to coexist (Pianka, 1974). Under limiting conditions, strong niche overlap between species may lead to strong competitive interactions, and may ultimately result in the competitive exclusion of the weakest competitor implying consequences on its local and regional distribution (Wisz et al., 2013). The study of resource use and potential niche overlap with competitors seems thus crucial to assess the vulnerability of species with

Abbreviations: $\mathrm{FO}_{\mathrm{diet}}$, frequency of occurrence of invertebrate taxa in the predator diet (number of faeces containing the taxon divided by the total number of

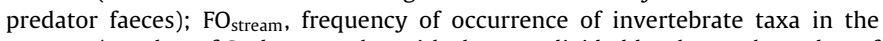
streams (number of Surber samples with the taxa divided by the total number of Surber samples collected in the study sites).

* Corresponding author.

E-mail address: m.biffi@live.fr (M. Biffi). conservation concern. This is particularly true when focusing on species living in ecosystems that are vulnerable to anthropogenic alterations, such as freshwater ecosystems (Dudgeon et al., 2006). Any quantitative or qualitative shift in the resource availability and/or diversity (e.g. prey community) following disturbance (e.g. aquatic pollution, alteration of river flow) may exacerbate the competitive interactions between consumers.

The Pyrenean desman, Galemys pyrenaicus (E. Geoffroy SaintHilaire, 1811, Talpidae) is a small semi-aquatic mammal, endemic to the Pyrenees Mountains and the Iberian Peninsula (northern and central Spain, northern Portugal). The species is listed as vulnerable by the IUCN (Fernandes et al., 2008) and is legally protected in all the countries encompassing its distribution area. The alarming decline of $G$. pyrenaicus populations over the recent decades across its whole range (Charbonnel et al., 2016; Gisbert and García-Perea, 2014) has encouraged local, national and European conservation initiatives (e.g., in France: Life+ Desman, 2013; Némoz et al., 2011). Yet, in spite of an increasing number of studies focusing on this species (e.g., Aymerich and Gosàlbez, 2015; Biffi et al., 2016; Charbonnel et al., 2016; Escoda et al., 2017), the respective influence of prey, competitors and predators on its survival and distribution still remains to be explored. 
Modern advances in molecular genetics were recently applied to investigate the diet of $G$. pyrenaicus in the French Pyrenees (Gillet, 2015; Gillet et al., 2015). They stressed the wide diversity of prey (156 genera) with half of them being found in the diet of $G$. pyrenaicus for the first time. Besides, these first studies confirmed the dietary preferences of $G$. pyrenaicus towards Trichoptera, Ephemeroptera and Plecoptera (Insecta), as previously known from traditional methods based on gut content analysis or visual inspection of faeces remains (e.g., Bertrand 1994; Castién and Gosálbez 1995; Santamarina 1993; Santamarina and Guitian 1988). In addition, Gillet (2015) emphasized a substantial consumption of terrestrial prey.

Several aquatic or semi-aquatic animals are known to prey and use similar food and habitat resources as G. pyrenaicus and act as potential competitors for resource acquisition: the brown trout Salmo trutta and the dipper Cinclus cinclus (Bertrand, 1994; Santamarina, 1993; Santamarina and Guitian, 1988), the Eurasian water shrew Neomys fodiens (Castién and Gosálbez 1999; Morueta-Holme et al., 2010; Santamarina and Guitian 1988), the Mediterranean water shrew Neomys anomalus (Santamarina, 1993) and the Pyrenean brook newt Calotriton asper (Bertrand, 1994). Among these species $N$. fodiens exhibits similar habitat preferences as $G$. pyrenaicus, i.e. swiftly-flowing streams with numerous shelters (e.g. cavities) on the riverbeds (Greenwood et al., 2002; Keckel et al., 2014). $N$. fodiens is also known as an opportunistic feeder consuming both aquatic (e.g., crustaceans, insect larvae) and terrestrial (e.g, coleopterans, gastropods, spiders, earthworms) prey (Castién and Gosálbez, 1999; Churchfield, 1985; Churchfield and Rychlik, 2006; Haberl, 2002). Moreover, N. fodiens exhibits a similar polyphasic activity pattern as G. pyrenaicus (Melero et al., 2014), with activity phases varying across seasons (Churchfield, 1984; Greenwood et al., 2002; Keckel et al., 2014; Rychlik, 2000). Despite important similarities in their habitat, resource preferences and life style, few studies have focused on the trophic overlap between $N$. fodiens and G. pyrenaicus to date. These studies, limited to small samples sizes (e.g., only six G. pyrenaicus samples in Santamarina, 1993) and relying solely on the visual inspection of prey remains in faeces or gut content, concluded that coexistence and diet differentiation were likely the result of a different use of micro-habitats (Castién and Gosálbez, 1999).

During the past years, molecular genetic methods based on faeces analyses were increasingly used instead of 'traditional' methods based on gut content analysis or visual inspection of faeces remains (Pompanon et al., 2012). Their main advantages are that (i) they do not request animal sacrifice compared to gut content analysis, (ii) they identify prey with high taxonomic resolution (genus and species levels), (iii) including highly degraded or soft-bodied species (molluscs, earthworms) that cannot be identified morphologically, (iv) they are less time consuming, and (v) they do not require any taxonomical expertise of the range of potential prey as long as taxa are present in genetic databases (see Pompanon et al., 2012 for a review). To date, though the diet of G. pyrenaicus has been recently described using molecular methods (Gillet, 2015; Gillet et al., 2015; Biffi et al., 2017), such data about $N$. fodiens have never been gathered, making any comparison of the respective diets of these two species rather speculative.

In this study, we aimed at describing the summer diet of these two mammals, using recent molecular genetic methods, in a part of the French Pyrenees (i.e., the Ariège department) where they are known to co-occur. Moreover, we compared the prey of these predator species with stream benthic invertebrate communities, on which G. pyrenaicus mostly feeds. This allowed us assessing the prey selectivity of these two mammal species and the potential trophic overlap during summer in order to discuss mechanisms that could facilitate their coexistence.

\section{Material and methods}

\section{Study area and sampling sites}

Sampling was conducted in 65 sites spread over the Ariège department, a French administrative region in the Pyrenees Mountains (Fig. 1). This area exhibits relatively high occurrence of $G$. pyrenaicus (Biffi et al., 2016; Charbonnel et al., 2015, 2016), and the presence of $N$. fodiens was recently reported (Charbonnel et al., 2015). The mean elevation of the 65 sampling sites is $757.9 \pm 259.3 \mathrm{~m}$ and varies between $375.2 \mathrm{~m}$ and $1755.6 \mathrm{~m}$. Mean monthly stream flow equals to $1.1 \pm 2.0 \mathrm{~m}^{3} / \mathrm{s}$ with a maximum of $13.2 \mathrm{~m}^{3} / \mathrm{s}$ (Charbonnel et al., 2016). Natural zones with herbaceous or shrubby vegetation $(52.1 \pm 36.1 \%)$, agricultural lands $(43.9 \pm 34.7 \%)$ and forests $(40.6 \pm 32.5 \%$; Corine Land Cover @ $\odot \mathrm{DB}$ 2012) dominate the land cover surrounding the 65 sites. In this mountainous area, the climate is cold (mean annual air temperature $=10.4 \pm 1.3^{\circ} \mathrm{C}$, SAFRAN (C) DB) and wet (mean annual rainfall $=1141.0 \pm 110.9 \mathrm{~mm}$, SAFRAN $@ \mathrm{DB})$.

\section{Faeces sampling and molecular genetics analyses}

Faeces collection of $G$. pyrenaicus and $N$. fodiens were conducted twice between June and September 2015 in the 65 selected sites (Fig. 1). Skilled observers meticulously inspected each emergent item (i.e., rock, tree root or branch) along a $250 \mathrm{~m}$ riverbed transect. This length is a compromise between the home range (HR) size and the average distance travelled along stream channels (ADTS) during $24 \mathrm{~h}$ for $N$. fodiens (narrow and linear HR along a stream: 106-509 $\mathrm{m}^{2}$, ADTS: 49 $\pm 25 \mathrm{~m}$; Cantoni, 1993; Lardet, 1988) and G. pyrenaicus (linear HR: $\approx 500 \mathrm{~m}$; ADTS between resting sites: $\approx 250 \mathrm{~m}$; Melero et al., 2012, 2014). Our sampling protocol meets the recommendations of Parry et al. (2013) who found that repeating visits in a single site rather than enlarging the sampled area allowed better detection probabilities for the Eurasian otter. It is also in agreement with Charbonnel et al. (2014) who obtained reasonable detection probabilities for $\mathrm{G}$. pyrenaicus $(0.58)$ in a survey of $100 \mathrm{~m}$-long sections of rivers using temporal replicates. The search for faeces is a standard and effective protocol for detecting the presence of $G$. pyrenaicus (Charbonnel et al., 2014) and has also proven efficiency for $N$. fodiens (Aymerich and Gosálbez, 2004).

All putative $G$. pyrenaicus or $N$. fodiens faeces based on their colour, size, smell and position, were collected and analysed with molecular genetic tools both to confirm the species identity of the consumer and the prey consumed. Following the manufacturer's instructions, DNA was extracted from faecal samples using the Stool Mini Kit (Qiagen Inc., Hilden, Germany). PCR amplification was duplicated for each sample on a portion of the mitochondrial cytochrome oxydase I gene (COI; for details, see Gillet et al., 2015). Negative DNA extraction and negative PCR controls were included in the procedure. Agencourt AMPure XP beads (Beckman Coulter Life Sciences, IN, USA) and then Quant-iT ${ }^{\mathrm{TM}}$ PicoGreen $^{\circledR}$ dsDNA Assay Kit (Thermo Scientific, MA, USA) were used to purified PCR products and to quantified purified amplicons respectively. After the quantification step, products were pooled at equimolarity and sent to the GIGA Genomics platform (University of Liège, Belgium) for sequencing on an ILLUMINA MiSeq V2 benchtop sequencer. Raw sequences were sorted and filtered using a script mixing FASTX Toolkit (http://hannonlab.cshl.edu/fastx_toolkit; 2309-16) and USEARCH (Edgar, 2010) functions (see André et al., 2017 for details on bioinformatics). Sequences originating likely from extraction or PCR contaminants were excluded from further analyses. The remaining sequences were then compared with published sequences available in the online BOLD database for COI (Ratnasingham and Hebert, 2007). Sequences that had a unique best-hit were considered to be positive matches with an identity 


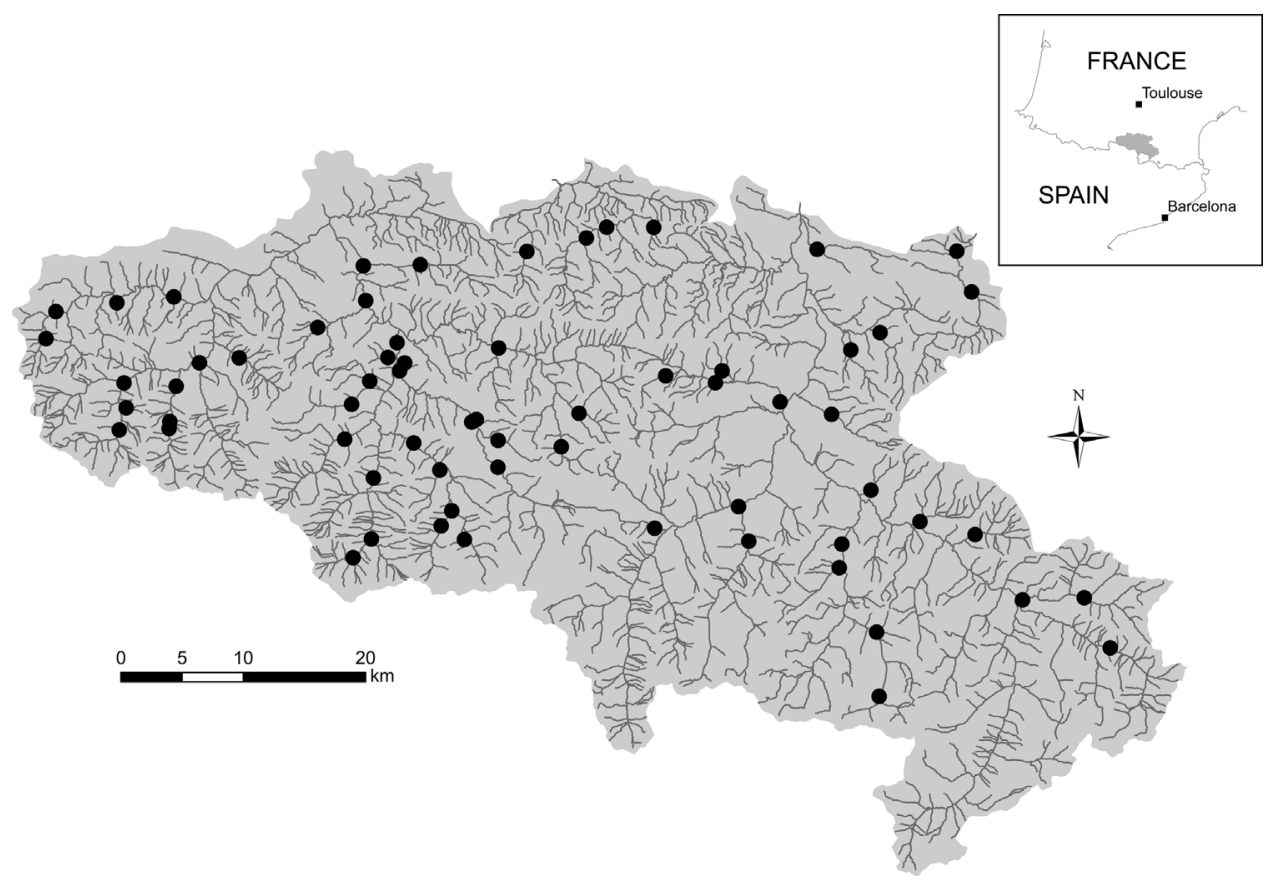

Fig. 1. Location of the study area and sampling sites (black dots) in France.

score (i) higher or equal to $90 \%$ for the identification of prey taxa at the genus level (when possible), and (ii) higher or equal to $99 \%$ for the identification of the predator at the species level.

Prey taxa were validated as potentially occurring in France and in the Pyrenees using the French National Inventory of Natural Heritage (Muséum national d'Histoire naturelle, 2003-2017) and the French Office for Insects and their Environment (OPIE-Benthos, 2017) online databases. Taxa identified as endemic of other parts of the world were kept in the analysis and designated by an asterisk hereafter $\left({ }^{*}\right)$ as they more likely correspond to a genetically similar taxon present in the Pyrenees but absent in the genetic databases. When prey taxa could not be identified at the genus level, they were grouped together at a higher taxonomic level.

\section{Aquatic macroinvertebrates sampling}

Aquatic macroinvertebrates were collected in 27 out of the 65 sites, among which $N$. fodiens and G. pyrenaicus were present in 19 and 25 sites, respectively (called "Neomys sites" and "Galemys sites", respectively). G. pyrenaicus was detected alone in eight sites ("Galemys alone sites") and both species were found to co-occur in 17 sites ("Galemys + Neomys sites"). N. fodiens was detected alone in two sites ("Neomys alone sites").

The available habitats for aquatic macroinvertebrates were described according to 12 categories of substrate type: bryophytes, hydrophytes, helophytes, litter, twigs roots, algae, large stones $(>25 \mathrm{~cm})$, cobbles/pebbles $(2.5-25 \mathrm{~cm})$, gravel $(0.2-2.5 \mathrm{~cm})$, mud, sand, bedrock; and four categories of current velocity: null, slow, medium, fast. The percentage cover of each combination of substrate type/current velocity was visually estimated in each site.

Six Surber net samples (mesh size: $500 \mu \mathrm{m}$, sampled area: $0.04 \mathrm{~m}^{2}$ ) were conducted in each site according to a stratified sampling in the dominant habitats (e.g. mainly coarse mineral substrate in high-flow facies) covering more than $5 \%$ of each stream transect in order to be representative of the site. The sampled macroinvertebrates were frozen before being sorted, counted and identified at the family level (except for Oligochaeta and Hydracarina) following Tachet et al. (2000) at the laboratory. The mean density (number of individuals $\left./ \mathrm{m}^{2}\right)$, and the frequency of occurrence $\left(\mathrm{FO}_{\text {stream }}\right.$ : relative number of Surber samples with the taxon) were then calculated for each site and invertebrate taxon.

Mean macroinvertebrates densities were compared with Wilcoxon sign-ranked tests and P-values adjusted with the Bonferroni correction, between categories of sites (i.e., Galemys alone sites, Neomys alone sites and Galemys + Neomys sites).

\section{Diet composition and comparison between mammals}

Presence or absence of prey in each faeces of G. pyrenaicus and $N$. fodiens were used to describe the diet composition of both species. The frequency of occurrence $\left(\mathrm{FO}_{\text {diet }}\right.$, i.e., the number of faeces containing the taxon divided by the total number of faeces) in $G$. pyrenaicus and $N$. fodiens diet was calculated for each order, family and genus of invertebrates and for the different types of prey's habitat (i.e., exclusively aquatic, exclusively terrestrial or with aquatic and terrestrial stages). To compare the faeces composition between the two species, a Correspondence Analysis (CA) was applied to presence-absence data of prey in faeces at the genus level. The coordinates of each faeces on the first and second axes of the CA were compared between the two species with a Student test for homogeneous variances. Rare prey taxa, with $\mathrm{FO}_{\text {diet }}$ below $5 \%$ both in $G$. pyrenaicus and $N$. fodiens faeces, were not included in this analysis.

To assess prey selectivity of G. pyrenaicus and N. fodiens, the presence of invertebrates in the faeces were considered at the site scale. When an invertebrate taxon was present in at least one faeces of the mammal species in a site, it was considered as belonging to the mammal diet in this site. Prey $\mathrm{FO}_{\text {diet }}$ in the faeces were then calculated for the 19 Neomys sites and the 25 Galemys sites. Data on prey availability in the streams (i.e., $\mathrm{FO}_{\text {stream }}$ per site from the Surber samples) and prey consumed by the predator in the site (i.e., $\mathrm{FO}_{\text {diet }}$ per site in the sampled faeces) at the family level were compared using the Ivlev's electivity index (Ivlev, 1961). This index ranges from -1 (i.e., avoidance of prey) indicating that the taxon is frequent in streams but never found in faeces, to 1 (i.e., active selection) when the taxon is rare in streams but found in a very high number of faeces. A zero value indicates that consumption is proportional to the amount of invertebrates available in streams. Invertebrate taxa with a mean frequency of occurrence lower than 
$5 \%$ in both the Surber samples $\left(\mathrm{FO}_{\text {stream }}\right)$ and the faeces of G. pyrenaicus and $N$. fodiens $\left(\mathrm{FO}_{\text {diet }}\right)$ were not considered in this analysis.

\section{Trophic overlap between mammals}

To determine the degree of trophic overlap between G. pyrenaicus and $N$. fodiens during summer, the Pianka's dietary niche overlap index (Pianka, 1973) was calculated from the prey $\mathrm{FO}_{\text {diet }}$ in the faeces at the genus and family levels. This index ranges from 0 (no trophic resource used in common) to 1 (full dietary overlap).

Moreover, to test if the co-occurrence of both mammal species in a site could modify the diet of G. pyrenaicus, the faeces composition in prey was compared between the Galemys alone sites (8) and the Galemys + Neomys sites (17). The mean frequency of occurrence of each prey taxon found in the faeces of $G$. pyrenaicus (at the family level) were compared with a Wilcoxon sign-ranked test between the two categories of sites. The diet of $N$. fodiens could not be compared between Neomys alone sites and Galemys + Neomys sites due to a very small number of Neomys alone sites (2).

All statistical analyses were conducted in R 3.3.1 (R Core Team, 2014) using the ade 4 and spaa packages.

\section{Results}

Molecular identification of predators producing the faeces and prey contents

A total of 464 faeces were collected from the 65 sampled sites ( $7 \pm 2$ faeces per site) and analysed using molecular genetics tools. After the two PCR amplifications, a total of 2,160,447 reads were obtained. 1,348,331 reads were correctly assigned to 199 faeces (42.9\%) that belonged to G. pyrenaicus ( $3 \pm 2$ faeces per site) and whose presence was confirmed in 58 sites. Among them, it was possible to identify prey in 184 faeces. Seventy-nine faeces $(17 \%$ of faeces - 463,706 reads), including 78 faeces with diet information, belonged to $N$. fodiens ( $2 \pm 1$ faeces per site) which confirmed its presence in 39 sites. From the remaining faeces, 51 (11.0\%) were assigned to 14 other host species (mammals such as Neomys anomalus, Apodemus sp., Sorex sp.; bats or birds). Molecular identification of predators and prey failed for $29.1 \%$ of the samples due to insufficient DNA quantity or degraded samples.

\section{Overall diversity of prey in the predator faeces}

The faeces of G. pyrenaicus and N. fodiens contained almost exclusively invertebrate prey except one amphibian found in one $G$. pyrenaicus faeces. Prey diversity was high with 10 and 9 classes, 30 and 33 orders (Table 1), 111 and 117 families, and 194 and 205 genera (Appendix A in the Supplementary material) for G. pyrenaicus and $N$. fodiens, respectively. In total, 309 different genera were identified whose 178 were confirmed to occur in the Pyrenees, 95 in France and 9 were endemic of other parts of the world (e.g., Australia, America, Asia). The remaining 27 taxa could not be identified at the genus level in the databases and their distribution range is unknown.

For the two mammal species, frequently consumed prey (i.e., present in more than $5 \%$ of the faeces) represented a small proportion of the total pool of prey consumed (12.9\% and $20.5 \%$ of genera eaten by $G$. pyrenaicus and $N$. fodiens, respectively). The dominant prey found in the faeces of G. pyrenaicus were Insecta (93.5\% of the faeces), Malacostraca (23.4\%) and Diplopoda (21.7\%). Among insects, G. pyrenaicus preyed more frequently on Ephemeroptera (71.2\%) which included the most frequent family (Heptageniidae: 61.4\%) but not the most frequent genera Hydropsyche (Insecta Trichoptera Hydropsychidae: 52.7\%). N. fodiens seemed to have a more diverse diet with Diplopoda (89.7\% of faeces), Insecta (83.3\%),
Arachnida (47.4\%), Gastropoda (25.6\%) and Malacostraca (24.3\%) occurring frequently in the collected faeces. The prey found the most frequently for this species belonged to the genus Glomeris (75.6\%).

About half of G. pyrenaicus prey belonged to Ephemeroptera, Plecoptera and Trichoptera orders while only $16.6 \%$ of prey belonged to these orders for $N$. fodiens. The proportion of exclusively terrestrial prey was higher for $N$. fodiens $(70.8 \pm 29.4 \%)$ than for G. pyrenaicus $(20.6 \pm 30.5 \%)$, while the proportion of prey with aquatic and terrestrial stages was higher for G. pyrenaicus $(74.6 \pm 31.4 \%)$ than for $N$. fodiens $(26.1 \pm 28.3 \%)$. Exclusively aquatic prey were marginal for both species.

Among the 309 identified genera in the faeces of both mammals, only 90 genera were consumed by both G. pyrenaicus and N. fodiens. The prey taxa consumed by only one of the two species were mostly exclusively terrestrial genera (52 and $80 \%$ in G. pyrenaicus and $N$. fodiens faeces, respectively).

Prey composition of faeces was significantly different between G. pyrenaicus and $N$. fodiens on the first axis of the CA (Student: $\mathrm{t}=14.2, \mathrm{df}=149.2, \mathrm{p}<0.001)$. This difference could be due to the majority of terrestrial prey in $N$. fodiens faeces in contrast with prey with both aquatic and terrestrial stages found more frequently in G. pyrenaicus faeces (Fig. 2).

\section{Aquatic macroinvertebrates availability}

In the 27 sites where stream invertebrates were sampled, $G$. pyrenaicus and $N$. fodiens consumed respectively 81 and 88 invertebrate families in total out of which 40 and 25 families included invertebrates with at least one aquatic stage in their life cycle.

From stream invertebrates samples, a total of 51 different invertebrate families were identified ( $27 \pm 5$ per site) among which 42 families of Insecta, 1 Malacostraca family, 1 Hydracarina family, 2 Gastropoda families, 1 Bivalvia family, 1 flatworm family, 2 Clitellata families and 1 Nematodes family. Insecta taxa had the highest mean densities in the Surber samples (Fig. 3a).

Nine invertebrate families (Rhagionidae, Caenidae, Mermithidae, Planariidae, Leptoceridae, Gyrinidae, Calopterygidae, Hydrophilidae, Psephenidae) were excluded from further analyses as they were found in the Surber samples and in faeces with $\mathrm{FO}_{\text {stream }}$ and $\mathrm{FO}_{\text {diet }}$ below 5\%. Conversely, one-quarter of the invertebrate families with at least one aquatic stage found in the faeces of both G. pyrenaicus and $N$. fodiens were not found in the invertebrates samples. This concerned 9 families out of 40 for $G$. pyrenaicus and 5 out of 25 families for $N$. fodiens. However, these families had a $\mathrm{FO}_{\text {diet }}$ below $10 \%$ in both diets, except the family Anthomyiidae (20\% in G. pyrenaicus diet and $10.5 \%$ in $N$. fodiens diet) and Thaumaleidae (10.5\% in $N$. fodiens diet), and were thus also excluded from further analyses.

Densities of available invertebrates were not significantly different between the Galemys alone sites, the Neomys alone sites and the Galemys + Neomys sites (Wilcoxon sign-ranked tests: all adjusted $p>0.05$ ) allowing the comparison of invertebrates content in faeces collected in the different categories of sites. Forty-six families and 50 families were available in Galemys alone sites and Galemys + Neomys sites respectively, including 45 families common to both types of sites.

\section{Prey selectivity between the two mammals}

Overall, the most frequently consumed prey by G. pyrenaicus corresponded to the most frequent and abundant invertebrate taxa in streams (Fig. 3a and b). Seven out of the nine most abundant prey were consumed in accordance with the frequency of occurrence and density estimated in the streams (Chironomidae, Baetidae, Heptageniidae, Gammaridae, Hydropsychidae, 
Table 1

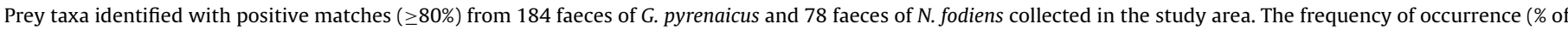

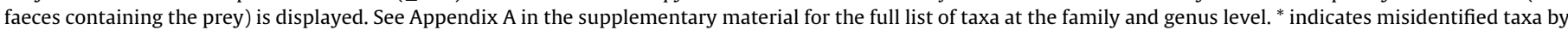
genetic databases.

\begin{tabular}{|c|c|c|c|c|c|}
\hline \multirow[t]{2}{*}{ Classes } & \multicolumn{2}{|c|}{ Frequency of occurrence (\%) } & \multirow[t]{2}{*}{ Orders } & \multicolumn{2}{|c|}{ Frequency of occurrence (\%) } \\
\hline & G. pyrenaicus & N. fodiens & & G. pyrenaicus & N. fodiens \\
\hline \multirow{14}{*}{ Insecta } & 93.5 & 83.3 & Ephemeroptera & 71.2 & 32.1 \\
\hline & & & Diptera & 65.8 & 50.0 \\
\hline & & & Trichoptera & 63.6 & 30.8 \\
\hline & & & Plecoptera & 52.7 & 35.9 \\
\hline & & & Coleoptera & 14.1 & 43.6 \\
\hline & & & Hemiptera & 3.8 & 17.9 \\
\hline & & & Lepidoptera & 3.3 & 11.5 \\
\hline & & & Hymenoptera & 1.6 & 9.0 \\
\hline & & & Odonata & 1.1 & 2.6 \\
\hline & & & Dermaptera & 0.5 & 1.3 \\
\hline & & & Neuroptera & 0.0 & 5.1 \\
\hline & & & Orthoptera & 0.0 & 1.3 \\
\hline & & & Mecoptera & 0.0 & 3.8 \\
\hline & & & Archaeognatha & 0.0 & 1.3 \\
\hline \multirow[t]{3}{*}{ Malacostraca } & 23.4 & 24.4 & Amphipoda & 20.7 & 19.2 \\
\hline & & & Isopoda & 3.3 & 6.4 \\
\hline & & & Decapoda & 0.5 & 0.0 \\
\hline \multirow[t]{4}{*}{ Diplopoda } & 21.7 & 89.7 & Glomerida & 15.8 & 80.8 \\
\hline & & & Polydesmida & 7.1 & 53.8 \\
\hline & & & Julida & 4.3 & 43.6 \\
\hline & & & Chordeumatida & 2.7 & 16.7 \\
\hline \multirow[t]{6}{*}{ Arachnida } & 8.2 & 47.4 & Araneae & 3.3 & 25.6 \\
\hline & & & Opiliones & 2.2 & 23.1 \\
\hline & & & Sarcoptiformes & 1.1 & 2.6 \\
\hline & & & Trombidiformes & 0.5 & 1.3 \\
\hline & & & Undetermined Arachnida* & 0.5 & 1.3 \\
\hline & & & Mesostigmata & 0.5 & 0.0 \\
\hline Clitellata & 6.0 & 17.9 & Haplotaxida & 6.0 & 17.9 \\
\hline \multirow[t]{2}{*}{ Gastropoda } & 4.3 & 25.6 & Stylommatophora & 3.3 & 25.6 \\
\hline & & & Hygrophila & 1.1 & 0.0 \\
\hline \multirow[t]{3}{*}{ Collembola } & 1.1 & 19.2 & Entomobryomorpha & 1.1 & 17.9 \\
\hline & & & Poduromorpha & 0.0 & 2.6 \\
\hline & & & Symphypleona & 0.0 & 1.3 \\
\hline Amphibia & 0.5 & 0.0 & Anura & 0.5 & 0.0 \\
\hline \multirow[t]{2}{*}{ Chilopoda } & 0.5 & 9.0 & Lithobiomorpha & 0.5 & 7.7 \\
\hline & & & Geophilomorpha & 0.0 & 1.3 \\
\hline Maxillopoda & 0.5 & 0.0 & Sessilia & 0.5 & 0.0 \\
\hline Undetermined Nemerta* & 0.0 & 2.6 & Undetermined Nemerta* & 0.0 & 2.6 \\
\hline
\end{tabular}

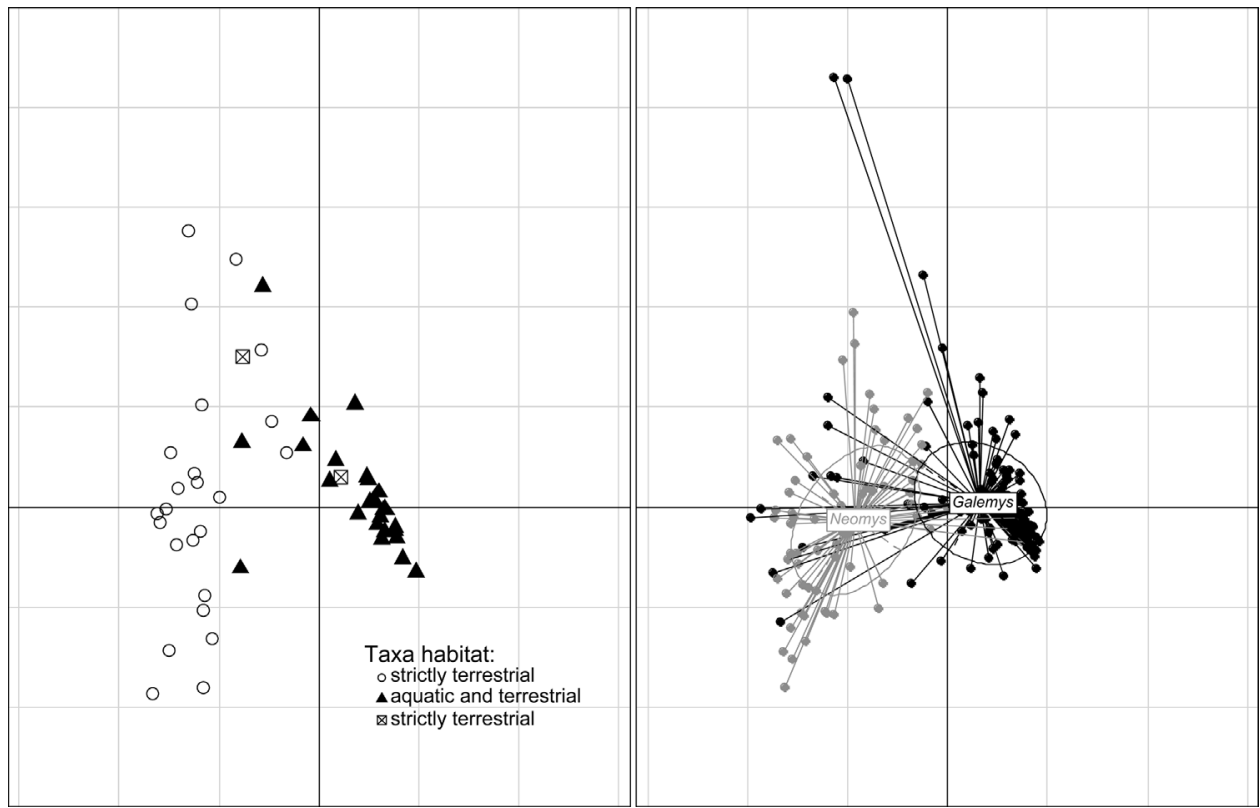

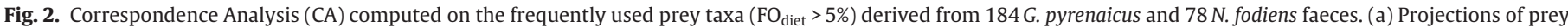

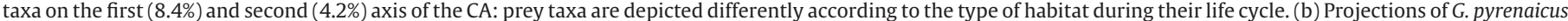
("Galemys") and N. fodiens ("Neomys") faeces on the first factorial plane. 


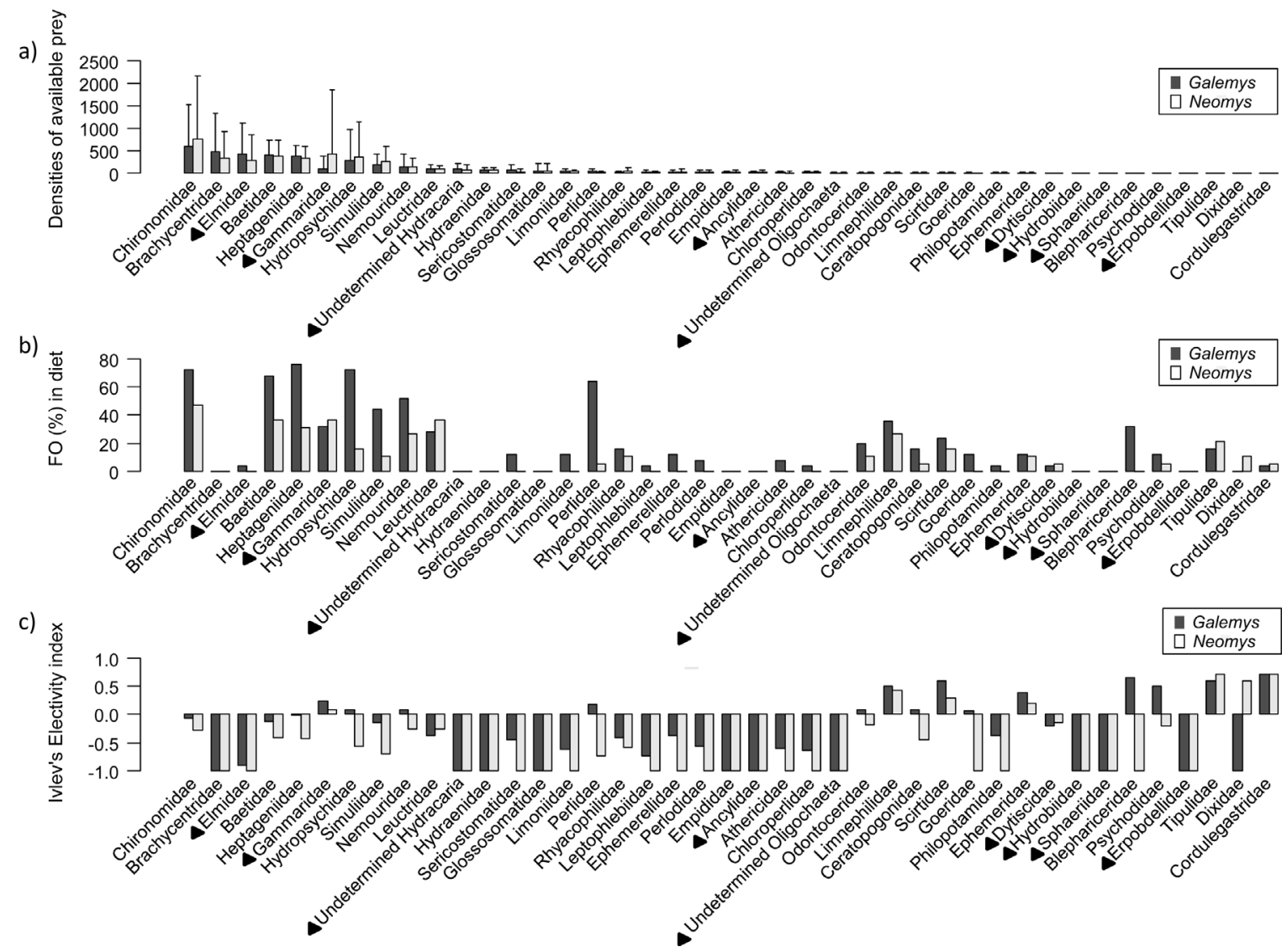

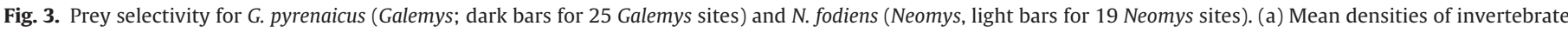

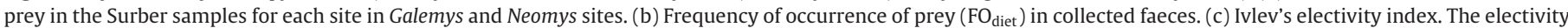

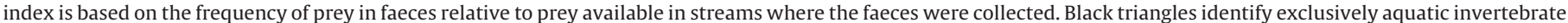
families as opposed to families without triangles that include invertebrates with at least one aquatic stage and one terrestrial stage in their life cycle.

Simulidae, Nemouridae; Fig. 3c). N. fodiens consumed Gammaridae according to their relative amount in the streams and avoided the other most abundant families.

However, most invertebrate families sampled in streams were avoided by $G$. pyrenaicus and $N$. fodiens with negative Ivlev's values below -0.25 for 22 and 31 available taxa out of 41 , respectively (Fig. 3c). Both G. pyrenaicus and N. fodiens seemed to avoid Brachycentridae and Elmidae prey in spite of their high densities in streams. An active selection of invertebrate prey was highlighted for seven families for G. pyrenaicus (Cordulegastridae, Blephariceridae, Tipulidae, Scirtidae, Limnephilidae, Psychodidae, Ephemeridae) and five families for $N$. fodiens (Cordulegastridae Dixidae, Limnephilidae, Scirtidae, Tipulidae).

\section{Trophic overlap between mammals}

The dietary overlap between $G$. pyrenaicus and $N$. fodiens was moderate at the genus (Pianka index $=0.4$ ) and family $(0.5)$ levels.

No difference in the $\mathrm{FO}_{\text {diet }}$ of the prey found in G. pyrenaicus faeces was detected at the family level between the sites with or without the presence of $N$. fodiens (Wilcoxon sign-ranked test: $\mathrm{V}=2748, \mathrm{p}=0.3$ ). When considering all consumed prey families, 72 were consumed by G. pyrenaicus in Galemys alone sites (38 with $\mathrm{FO}_{\text {diet }}>5 \%$ ) and 86 in Galemys + Neomys sites ( 44 with $\mathrm{FO}_{\text {diet }}>5 \%$ ). Only 47 taxa were consumed in both categories of sites. Ratios between numbers of rare prey (i.e., $\mathrm{FO}_{\text {diet }}<5 \%$ ) and frequent prey (i.e., $\mathrm{FO}_{\text {diet }}>5 \%$ ) in G. pyrenaicus diet were similar (around $50 \%$ ) in Galemys alone sites and in Galemys + Neomys sites.

\section{Discussion}

Novel insights into the diet of G. pyrenaicus and N. fodiens during summer

This study provides additional support to the usefulness of molecular genetic tools in diet analyses, as it provides an enhanced identification of prey content from indirect signs of presence (i.e., faeces) of predators. The proportion of faeces misidentification in the field (i.e., belonging to other host species: $11 \%$ ) or unidentified faeces in the laboratory (29\%) are consistent with previous studies of G. pyrenaicus diet (Gillet, 2015) confirming the issues arising from visual identification of faeces and DNA extraction from degraded faeces.

From the 194 invertebrate genera identified in the faeces of $G$. pyrenaicus in the present study, only 61 were common with the 156 genera identified in a previous study using similar genetic methods but conducted in the whole French Pyrenees (Gillet, 2015; Biffi et al., 2017). Newly identified prey included an amphibian, aquatic and terrestrial snails, leeches, earwigs, Hydracarina, Chilopoda, Maxillopoda and Collembola.

This study also provides unprecedented insights into the summer trophic niche of $N$. fodiens, by identifying prey identity at the family and genus levels for the first time (but see at the order level: Castién and Gosálbez, 1999; Churchfield, 1985; Churchfield and Rychlik, 2006). In accordance with previous studies conducted at a higher taxonomic level, we found that $N$. fodiens fed on terrestrial prey at a larger extent than G. pyrenaicus, with a dominance of terrestrial Diplopoda and Insecta in its diet. The proportion of 
Ephemeroptera, Plecoptera and Trichoptera was low (about 17\%) compared to G. pyrenaicus (55\%).

The density and species composition of stream invertebrate communities described in this study are consistent with previous reports of freshwater invertebrate fauna of the French Pyrenees (e.g., Brown et al., 2006; Finn et al., 2013). Both G. pyrenaicus and $N$. fodiens exhibited rather non-selective foraging strategies as the most frequently consumed invertebrates were also the most frequent and abundant in the streams. This supported a generalist diet for both species in the study area although a significant number of taxa were consumed in lower or higher frequencies than expected (Fig. 3).

$N$. fodiens avoided a higher number of prey and actively selected a smaller number of prey than G. pyrenaicus in the aquatic environment. This supports the difference in trophic niches between the two species, with more terrestrial taxa in N. fodiens diet compared with G. pyrenaicus. This latter species has morphological features adapted to live in aquatic environments (e.g., webbed feet, Palmeirim, 1983; Puisségur, 1935; high diving skills: 1-4 min, Richard and Micheau, 1975 compared to 3-24s for N. fodiens, Lardet, 1988; Mendes-Soares and Rychlik, 2009) that likely result in a better efficiency in the capture of aquatic prey than $N$. fodiens.

Foraging efficiency may determine prey selectivity in order to maximise individual success. It depends on the balance between the energy provided by prey consumption and the energetic costs of foraging under water. The most valuable resources may thus correspond to easy-to-catch prey with low mobility (e.g., Trichoptera) and/or high abundance (e.g., Gammaridae), soft-bodied prey that can be completely digested (e.g., in contrast with small and chitinous Hydracarina or Coleoptera, Costa et al., 2015) or large prey (Bertrand, 1994). In this study, invertebrates with hard and chitinous bodies (e.g. Elmidae, Hydraenidae Hydracarina) and hard cases made of wood (Brachycentridae) or mineral materials (Glossossomatidae, Sericostomatidae) were avoided by both $G$. pyrenaicus and $N$. fodiens.

Some of our results about prey selectivity by G. pyrenaicus contradict previous observations by Bertrand (1994) and Santamarina (1993). For instance, Rhyacophilidae were avoided and Limnephilidae actively selected by G. pyrenaicus in our study whereas the opposite was observed by Bertrand (1994). Chironomidae were avoided and Sericostomatidae actively selected in Santamarina (1993) whereas we found the opposite pattern for these families. These differences may be due to different sampling methods (stomach analyses $v s$. digested remains in faeces vs. molecular analyses) as well as sample sizes. They may also reflect the generalist diet of G. pyrenaicus that may vary between regions (i.e., a catchment of Spain vs. the whole French Pyrenees vs. a sub-region of the French Pyrenees) and seasons (Santamarina, 1993). Finally, the variability in life-history traits within and between invertebrate species of the same family or genus (e.g., development stage, body size, local adaptations) may influence their exposure to predation.

\section{Trophic overlap between mammals}

The faeces and aquatic invertebrates samplings were conducted during summer when many late instars of aquatic insects have emerged from mountain streams and left the aquatic environment (Füreder et al., 2004). Invertebrate communities are dominated by small-sized invertebrates for this period. This impoverishment in prey diversity and density may exacerbate the trophic overlap between their predators, such as G. pyrenaicus and N. fodiens, compared to the rest of the year. In spite of this, the Pianka's index of trophic overlap between the two species equalled 0.4 indicating a significant but rather low overlap in the summer diets. This value is consistent with a previous estimate of overlap (Castién and Gosálbez, 1999).
G. pyrenaicus consumed a larger number of different prey in the sites where $N$. fodiens was also present. This increase was driven by a higher consumption of terrestrial taxa but was not linked to any increase in rare prey consumption as ratios of rare prey/frequent prey were similar in sites with or without $N$. fodiens. However, no significant difference was found in diet composition of $G$. pyrenaicus between sites where $N$. fodiens was detected or not. All these results suggest no evidence of a shift of G. pyrenaicus diet towards suboptimal prey in the presence of another insectivore species with similar feeding strategies.

The absence of shift in G. pyrenaicus diet in the presence of $N$. fodiens could result from the non-limiting trophic resources in streams and/or on terrestrial habitats during summer. Actually, the measure of niche overlap may mostly reflect the potential competition in the case of limiting resources (Abrams, 1980).

It could also be due to resource partitioning between G. pyrenaicus and $N$. fodiens. First, asynchrony of seasonal or daily activity periods may play an important role in resource partitioning and facilitate cohabitation (e.g., Harrington et al., 2009). A temporal shift of niche has been observed in herbivores to reduce the length of the trophic overlap at waterholes during arid seasons (Valeix et al., 2007). Radiotracking conducted on a few individuals of $G$. pyrenaicus and $N$. fodiens seems to indicate polyphasic activity patterns (Lardet, 1988; Melero et al., 2014; Stone, 1987) with a similar timing of activity during day and night periods. This suggests that this mechanism is probably not involved in the resource partitioning between these two species.

Second, successful resource partitioning may be related to how the predators access to food resources according to their foraging strategies. The segregation of trophic niches based on differentiation of foraging modes and foraging micro-habitats is well documented among shrews (e.g., Churchfield and Rychlik, 2006; Churchfield and Sheftel, 199). First, G. pyrenaicus and N. fodiens have different body size (i.e., $10-15 \mathrm{~cm}$ vs. 7-9 cm without the tail for $G$. pyrenaicus and $N$. fodiens, respectively) and mass (i.e., 50-60 g vs. 8-17g for G. pyrenaicus and $N$. fodiens, respectively). Due to this difference of size, the two species could target contrasted development stage and prey size within a given taxa, as it is known to allow resource partitioning among shrew species (Churchfield et al., 1999). Second, the use of different habitat strata was also identified in small mammal communities to modulate the intensity of interspecific competition (Castién and Gosálbez, 1999; Churchfield and Sheftel, 1994; Rychlik, 1997). Specialization on particular microhabitats in streams is also known for other semi-aquatic mammals. For instance, the platypus Ornithorhynchus anatinus does not allocate an equal foraging effort to benthic macroinvertebrates across all habitats, its preference going to pools and littoral margins rather than riffles (McLachlan-Troup et al., 2010). The overall low selectivity, active selection or avoidance of different taxa, together with the distinct trophic niche we observed in the whole study area in G. pyrenaicus and N. fodiens, suggest that they use distinct foraging micro-habitats (Castién and Gosálbez, 1999) within the stream and riparian mosaic. Other aquatic predators such as the brown trout S. trutta could have higher diet overlap with G. pyrenaicus due to their broad use of habitats within streams and highly opportunistic feeding strategies (Giller and Greenberg, 2015).

\section{Methodological considerations and perspectives}

While molecular methods provide an enhanced identification of prey compared to traditional methods (i.e., visual inspection of prey remains in guts or faeces), they also have some shortcomings. First, identifying many additional prey taxa with molecular tools compared to traditional methods is consistent with Clare et al. (2014) who suggest that prey occurrence data obtained from molecular methods tend to underestimate the importance of common 
prey and overestimate rare prey (Clare et al., 2014; Krüger et al., 2014). Nevertheless, 20 taxa identified, such as Collembola or several genus of the Tachinidae family, are unlikely to be direct prey of G. pyrenaicus or N. fodiens, as they are part of the soil microfauna or are invertebrate parasites. Other taxa, such as some Anthomyiidae (e.g. Polietes) or small terrestrial Coleoptera, may have been collected with the faeces as they may develop at the larval stage or feed on scat. Finally, taxa identified as prey could have been passively ingested with the consumption of predator or scavenger invertebrates (e.g. Trichoptera, Plecoptera, Odonata). This contributes to the debate about the high sensitivity of next-generation sequencing methods and the detection of secondary predation (Sheppard et al., 2005).

Second, molecular data do not give information on the stage or size at which prey are consumed. This is a particularly strong limitation when (i) feeding strategies are adapted to the mouth morphology and size of the predator or (ii) prey exhibit important variation in habitat use during their life cycle such as many aquatic invertebrate species. Given the relative shortness of the terrestrial stage in comparison with the aquatic stage for many invertebrate species, the probability that invertebrates found in the faeces were consumed at the aquatic stage (or at the time of emergence) remains high, which is supported by previous morphological identification of prey items in faecal samples (Trichoptera; e.g., Bertrand, 1994; DuPasquier and Cantoni, 1992). The combination of molecular and traditional methods of prey identification seems thus important to bring detailed information on the identity, size and stage of eaten prey.

Third, the molecular data we used do not allow a quantitative assessment of the prey consumed (e.g. relative and absolute abundance/biomass of different taxa). Klare et al. (2011) stated that such qualitative estimates (i.e., presence-absence and frequency of occurrence of prey) tend to overestimate niche breadth and dietary overlaps between species leading potentially to unreliable conclusions. However, they also pointed out that such bias remains low when the diets of the compared species are composed of similar taxonomic groups of prey, which is the case for G. pyrenaicus and $N$. fodiens. Moreover, the likely bias in diet estimation due to the use of frequencies of occurrence is similar between $G$. pyrenaicus and $N$. fodiens which enables a reliable qualitative comparison of diet overlap and prey selection patterns in terms of prey identity. This is supported by the Pianka index of trophic niche overlap quantified in this study which is consistent with previous observations based on quantitative methods of prey estimates.

Despite those limitations, molecular methods proved efficiency in the identification of a highly diverse diet for G. pyrenaicus and $N$. fodiens that were highlighted to exhibit a generalist feeding behaviour. This suggests that the identity of prey taxa is not the most important criteria for both mammals prey selection and that they may exhibit some tolerance to variation in prey community composition. Hence, stream community changes due to anthropogenic impacts on river ecosystems should have moderate consequences (Costa et al., 2015) as long as food resources remain abundant enough in their respective foraging habitats. However, pressures on prey communities could increase the trophic overlap between the two species as well as with others potential competitors.

This study also stressed that the presence of $N$. fodiens did not affect $G$. pyrenaicus prey selection. However, the higher proportion of exclusively terrestrial prey in $N$. fodiens diet found here compared to other dietary studies (e.g. Churchfield, 1984; DuPasquier and Cantoni, 1992) may suggest a shift in the diet of $N$. fodiens towards a more terrestrial niche in presence of $G$. pyrenaicus. The very small number of sites hosting $N$. fodiens without G. pyrenaicus did unfortunately prevent us to test for this potential competitive interaction.
Identifying more finely the foraging micro-habitats of G. pyrenaicus and $N$. fodiens, comparing the diet of $N$. fodiens in presence and absence of $G$. pyrenaicus and observing their behavioural interactions in the field along the year should be further investigated in the light of terrestrial invertebrates sampling and the use of dietary quantitative data (e.g. abundance or biomass of prey in scats). This would improve our knowledge about mechanisms facilitating their cohabitation or causing potential competitive interactions and their vulnerability to habitat and trophic resource alterations.

\section{Acknowledgements}

We are grateful to all people who helped collecting data in the field: C. Dupuyds, M. Alvarez., C. Lauzeral, F. Colas, F. Julien and V. Lacaze. We also thank the "Conservatoire d'Espaces Naturels MidiPyrénées" (CEN-MP), especially M. Némoz and F. Blanc, for their precious advice at many steps of the study. This study was funded by ANRT (Cifre $n^{\circ}$ 2011/1018), EDF (Electricité de France) and the European Union (FEDER) in the context of the LIFE+ Nature programme devoted to G. pyrenaicus (LIFE13NAT/FR/000092). M. Biffi was supported by a PhD fellowship granted by the "Ecole Doctorale Sciences de l'Univers, de l'Environnement et de l'Espace" (SDU2E) at the University of Toulouse.

\section{Appendix A. Supplementary data}

Supplementary data associated with this article can be found, in the online version, at http://dx.doi.org/10.1016/j.mambio.2017.09. 001.

\section{References}

Abrams, P., 1980. Some comments on measuring niche overlap. Ecology 61, 44-49. André, A., Mouton, A., Millien, V., Michaux, J., 2017. Liver microbiome of Peromyscus leucopus, a key reservoir host species for emerging infectious diseases in North America. Infect. Genet. Evol. 52, 10-18.

Aymerich, P., Gosàlbez, J., 2015. Evidencias de regresión local del desmán ibérico (Galemys pyrenaicus) en los Pirineos meridionales. Galemys 27, 31-40.

Aymerich, P., Gosálbez, J., 2004. La prospección de excrementos como metodología para el estudio de la distribución de los musgaños (Neomys sp.). Galemys 16, 83-90.

Bertrand, A., 1994. Répartition géographique et écologie alimentaire du desman des Pyrénées, Galemys pyrenaicus (Geoffroy, 1811) dans les Pyrénées françaises. Thèse de doctorat. Université Paul Sabatier de Toulouse (50pp).

Biffi, M., Charbonnel, A., Buisson, L., Blanc, F., Némoz, M., Laffaille, P., 2016. Spatial differences across the French Pyrenees in the use of local habitat by the endangered semi-aquatic Pyrenean desman (Galemys pyrenaicus). Aquat. Conserv. Mar. Freshw. Ecosyst. 26, 761-774.

Biffi, M., Gillet, F., Laffaille, P., Colas, F., Aulagnier, A., Blanc, F., Galan, M., Tiouchichine, M.-L., Némoz, M., Buisson, L., Michaux, J.R., 2017. Novel insights into the diet of the Pyrenean desman (Galemys pyrenaicus) using next-generation sequencing molecular analyses. J. Mammal., http://dx.doi.org/ 10.1093/jmammal/gyx070.

Brown, L.E., Milner, A.M., Hannah, D.M., 2006. Stability and persistence of alpine stream macroinvertebrate communities and the role of physicochemical habitat variables. Hydrobiologia 560, 159-173.

Cantoni, D., 1993. Social and spatial organization of free-ranging shrews, Sorex coronatus and Neomys fodiens (Insectivora, Mammalia). Anim. Behav. 45, 975-995.

Castién, E., Gosálbez, J., 1995. Diet of Galemys pyrenaicus (Geoffroy, 1811) in the North of the Iberian peninsula. Neth. J. Zool. 45, 422-430.

Castién, E., Gosálbez, J., 1999. Habitat and food preferences in a guild of insectivorous mammals in the Western Pyrenees. Acta Theriol. 44, 1-13.

Charbonnel, A., D’Amico, F., Besnard, A., Blanc, F., Buisson, L., Némoz, M., Laffaille, P., 2014. Spatial replicates as an alternative to temporal replicates for occupancy modelling when surveys are based on linear features of the landscape. J. Appl. Ecol. 51, 1425-1433.

Charbonnel, A., Buisson, L., Biffi, M., D’Amico, F., Besnard, A., Aulagnier, S., Blanc, F., Gillet, F., Lacaze, V., Michaux, J.R., Némoz, M., Pagé, C., Sanchez-Perez, J.M., Sauvage, S., Laffaille, P., 2015. Integrating hydrological features and genetically validated occurrence data in occupancy modelling of an endemic and endangered semi-aquatic mammal, Galemys pyrenaicus, in a Pyrenean catchment. Biol. Conserv. 184, 182-192.

Charbonnel, A., Laffaille, P., Biffi, M., Blanc, F., Maire, A., Némoz, M., Sanchez-Perez, J.M., Sauvage, S., Buisson, L., 2016. Can recent global changes explain the 
dramatic range contraction of an endangered semi-aquatic mammal species in the French Pyrenees? PLoS One 11, e0159941.

Churchfield, S., Rychlik, L., 2006. Diets and coexistence in Neomys and Sorex shrews in Białowieża forest, eastern Poland. J. Zool. 269, 381-390.

Churchfield, S., Sheftel, B.I., 1994. Food niche overlap and ecological separation in a multi-species community of shrews in the Siberian taiga. J. Zool. 234, 105-124.

Churchfield, S., Nesterenko, V.A., Shvarts, E.A., 1999. Food niche overlap and ecological separation amongst six species of coexisting forest shrews (Insectivora: soricidae) in the Russian Far East. J. Zool. 248, 349-359.

Churchfield, S., 1984. An investigation of the population ecology of syntopic shrews inhabiting water-cress beds. J. Zool. Lond. 204, 229-240.

Churchfield, S., 1985. The feeding ecology of the European water shrew. Mammal Rev. 15, 13-21.

Clare, E.L., Symondson, W.O.C., Broders, H., Fabianek, F., Fraser, E.E., MacKenzie, A., Boughen, A., Hamilton, R., Willis, C.K.R., Martinez-Nuñez, F., Menzies, A.K., Norquay, K.J.O., Brigham, M., Poissant, J., Rintoul, J., Barclay, R.M.R., Reimer, J.P., 2014. The diet of Myotis lucifugus across Canada: assessing foraging quality and diet variability. Mol. Ecol. 23, 3618-3632.

Costa, A., Salvidio, S., Posillico, M., Matteucci, G., De Cinti, B., Romano, A., 2015. Generalisation within specialization: inter-individual diet variation in the only specialized salamander in the world. Sci. Rep. 5, 13260.

DuPasquier, A., Cantoni, D., 1992. Shifts in benthic macroinvertebrate community and food habits of water shrew, Neomys fodiens (Soricidae, Insectivora). Acta OEcologica OEcal. Gener. 13, 81-99.

Dudgeon, D., Arthington, A.H., Gessner, M.O., Kawabata, Z.-I., Knowler, D.J., Lévêque, C., Naiman, R.J., Prieur-Richard, A.-H., Soto, D., Stiassny, M.L.J., Sullivan, C.A., 2006. Freshwater biodiversity: importance, threats, status and conservation challenges. Biol. Rev. 81, 163-182.

Edgar, R.C., 2010. Search and clustering orders of magnitude faster than BLAST. Bioinforma. Oxf. Engl. 26, 2460-2461.

Escoda, L., González-Esteban, J., Gómez, A., Castresana, J., 2017. Using relatedness networks to infer contemporary dispersal: application to the endangered mammal Galemys pyrenaicus. Mol. Ecol., http://dx.doi.org/10.1111/mec. 14133.

Füreder, L., Wallinger, M., Burger, R., 2004. Longitudinal and seasonal pattern of insect emergence in alpine streams. Aquat. Ecol. 39, 67-78.

Fernandes, M., Herrero, J., Aulagnier, S., Amori, G., 2008. Galemys Pyrenaicus. The IUCN Red List of Threatened Species. Version 2014.2 (<www.iucnredlist.org> Downloaded on 1 June 2014) http://dx.doi.org/10.2305/IUCN.UK.2008.RLTS. T8826A12934876.en.

Finn, D.S., Khamis, K., Milner, A.M., 2013. Loss of small glaciers will diminish beta diversity in Pyrenean streams at two levels of biological organization. Glob. Ecol. Biogeogr. 22, 40-51.

Giller, P., Greenberg, L., 2015. The relationship between individual habitat use and diet in brown trout. Freshw. Biol. 60, 256-266.

Gillet, F., Tiouchichine, M.-L., Galan, M., Blanc, F., Némoz, M., Aulagnier, S. Michaux, J.R., 2015. A new method to identify the endangered Pyrenean desman (Galemys pyrenaicus) and to study its diet, using next generation sequencing from faeces. Mamm. Biol. 80, 505-509.

Gillet, F., 2015. Génétique et biologie de la conservation du desman des Pyrénées (Galemys pyrenaicus) en France. Thèse de doctorat, Université Paul Sabatier de Toulouse (France)/Université de Liège (Belgique), 228pp.

Gisbert, J., García-Perea, R., 2014. Historia de la regresión del desmán ibérico Galemys pyrenaicus (É. Geoffroy Saint-Hilaire, 1811) en el Sistema Central (Península Ibérica). Conservation and management of semi-aquatic mammals of southwestern Europe. Munibe Monogr. Nat. Ser., 3., pp. 19-35.

Greenwood, A., Churchfield, S., Hickey, C., 2002. Geographical distribution and habitat occurrence of the water shrew (Neomys fodiens) in the Weald of South-East England. Mammal Rev. 32, 40-50

Haberl, W., 2002. Food storage, prey remains and notes on occasional vertebrates in the diet of the Eurasian water shrew, Neomys fodiens. Folia Zool. 51, 93-102.

Harrington, L.A., Harrington, A.L., Yamaguchi, N., Thom, M.D., Ferreras, P., Windham, T.R., Macdonald, D.W., 2009. The impact of native competitors on an alien invasive: temporal niche shifts to avoid interspecific aggression? Ecology 90, 1207-1216.

Hutchinson, G.E., 1957. Concluding remarks. Cold Spring Harb. Symp. Quant. Biol. $22,415-427$.

Ivlev, V.S., 1961. Experimental Ecology of Feeding Fishes. Yale University Press, New Haven, Connecticut (302 pp).

Keckel, M.R., Ansorge, H., Stefen, C., 2014. Differences in the microhabitat preferences of Neomys fodiens (Pennant 1771) and Neomys anomalus Cabrera 1907 in Saxony. Germany. Acta Theriol. 59, 485-494.

Klare, U., Kamler, J.F., Macdonald, D.W., 2011. A comparison and critique of different scat-analysis methods for determining carnivore diet. Mammal Review 41, 294-312.

Krüger, F., Clare, E.L., Greif, S., Siemers, B.M., Symondson, W.O.C., Sommer, R.S., 2014. An integrative approach to detect subtle trophic niche differentiation in the sympatric trawling bat species Myotis dasycneme and Myotis daubentonii. Mol. Ecol. 23, 3657-3671.
Lardet, J.-P., 1988. Spatial behaviour and activity patterns of the water shrew Neomys fodiens in the field. Acta Theriol. 33, 293-303.

Life+ Desman, 2013. Technical Application Forms - Conservation of the French Populations of Galemys Pyrenaicus and Its Populations on the French Pyrénées (LIFE13 NAT/FR/000092). 274 p.

McLachlan-Troup, T.A., Dickman, C.R., Grant, T.R., 2010. Diet and dietary selectivity of the platypus in relation to season, sex and macroinvertebrate assemblages. J. Zool. 280, 237-246.

Melero, Y., Aymerich, P., Luque-Larena, J.J., Gosálbez, J., 2012. New insights into social and space use behaviour of the endangered Pyrenean desman (Galemys pyrenaicus). Eur. J. Wildl. Res. 58, 185-193.

Melero, Y., Aymerich, P., Santulli, G., Gosálbez, J., 2014. Activity and space patterns of Pyrenean desman (Galemys pyrenaicus) suggest non-aggressive and non-territorial behaviour. Eur. J. Wildl. Res. 60, 707-715.

Mendes-Soares, H., Rychlik, L., 2009. Differences in swimming and diving abilities between two sympatric species of water shrews: Neomys anomalus and Neomys fodiens (Soricidae). J. Ethol. 27, 317-325

Morueta-Holme, N., Fløjgaard, C., Svenning, J.-C., 2010. Climate change risks and conservation implications for a threatened small-range mammal species. PLoS One 5, e10360.

Muséum national d'Histoire naturelle [Ed]. 2003-2017. Inventaire National du Patrimoine Naturel. https://inpn.mnhn.fr. Accessed 15 May 2016.

Némoz, M., Bertrand, A., Sourie, M., Arlot, P., 2011. A french conservation action plan for the pyrenean desman Galemys pyrenaicus. Galemys 23, 47-50.

OPIE-Benthos, 2017. Office Pour les Insectes et leur Environnement (http://www.opie-benthos.fr/opie/insecte.php. Accessed 15 May 2016).

Palmeirim, J.M., 1983. Galemys pyrenaicus. Mamm. Species 207, 1-5.

Parry, G.S., Bodger, O., McDonald, R.A., Forman, D.W., 2013. A systematic re-sampling approach to assess the probability of detecting otters Lutra lutra using spraint surveys on small lowland rivers. Ecol. Inform. 14, 64-70 (The analysis and application of spatial ecological data to support the conservation of biodiversity)

Pianka, E.R., 1973. The structure of lizard communities. Annu. Rev. Ecol. Syst. 4, 53-74.

Pianka, E.R., 1974. Niche overlap and diffuse competition. Proc. Natl. Acad. Sci. 71, 2141-2145.

Pompanon, F., Deagle, B.E., Symondson, W.O.C., Brown, D.S., Jarman, S.N., Taberlet, P., 2012. Who is eating what: diet assessment using next generation sequencing. Mol. Ecol. 21, 1931-1950.

Puisségur, C., 1935. Recherches sur le Desman des Pyrénées. Bull. Soc. Hist. Nat. Toulouse 67, 163-227.

R Core Team, 2014. R: A Language and Environment for Statistical Computing. R Foundation for Statistical Computing, Vienna, Austria http://www.R-project. org/.

Ratnasingham, S., Hebert, P.D.N., 2007. BOLD: the barcode of life data system (www.barcodinglife.org). Mol. Ecol. Notes 7, 355-364.

Richard, P.B., Micheau, C., 1975. Le carrefour trachéen dans l'adaptation du desman des Pyrénées (Galemys pyrenaicus) à la vie dulçaquicole. Mammalia 39, 467-478.

Rychlik, L., 1997. Differences in foraging behaviour between water shrews: Neomys anomalus and Neomys fodiens. Acta Theriol. 42, 351-386.

Rychlik, L., 2000. Habitat preferences of four sympatric species of shrews. Acta Theriol. 45 (Suppl. 1), 173-190.

Santamarina, J., Guitian, J., 1988. Quelques données sur le régime alimentaire du desman (Galemys pyrenaicus) dans le nord-ouest de l'Espagne. Mammalia 52, 302-307.

Santamarina, J., 1993. Feeding ecology of a vertebrate assemblage inhabiting a stream of NW Spain (Riobo; Ulla basin). Hydrobiologia 252, 175-191.

Sheppard, S.K., Bell, J., Sunderland, K.D., Fenlon, J., Skervin, D., Symondson, W.O.C., 2005. Detection of secondary predation by PCR analyses of the gut contents of invertebrate generalist predators. Mol. Ecol. 14, 4461-4468.

Stone, R.D., 1987. The activity patterns of the Pyrenean desman (Galemys pyrenaicus) (Insectivora: talpidae), as determined under natural conditions. J. Zool. 213, 95-106.

Tachet, H., Richoux, P., Bournaud, M., Usseglio-Polatera, P., 2000. Invertébrés d'eau douce. Systématique, Biologie, Ecologie, CNRS Editions, Paris.

Valeix, M., Chamaillé-Jammes, S., Fritz, H., 2007. Interference competition and temporal niche shifts: elephants and herbivore communities at waterholes. Oecologia 153, 739-748.

Wisz, M.S., Pottier, J., Kissling, W.D., Pellissier, L., Lenoir, J., Damgaard, C.F., Dormann, C.F., Forchhammer, M.C., Grytnes, J.-A., Guisan, A., Heikkinen, R.K., Høye, T.T., Kühn, I., Luoto, M., Maiorano, L., Nilsson, M.-C., Normand, S., Öckinger, E., Schmidt, N.M., Termansen, M., Timmermann, A., Wardle, D.A., Aastrup, P., Svenning, J.-C., 2013. The role of biotic interactions in shaping distributions and realised assemblages of species: implications for species distribution modelling. Biol. Rev. 88, 15-30. 